\title{
Characterization of Porous Phosphate Coatings Enriched with Calcium, Magnesium, Zinc and Copper Created on CP Titanium Grade 2 by Plasma Electrolytic Oxidation
}

\author{
Krzysztof Rokosz ${ }^{1, *}$, Tadeusz Hryniewicz ${ }^{1}$, Wojciech Kacalak ${ }^{1}$, Katarzyna Tandecka ${ }^{1}$, \\ Steinar Raaen ${ }^{2}$, Sofia Gaiaschi ${ }^{3}$, Patrick Chapon ${ }^{3}$, Winfried Malorny ${ }^{4}$, Dalibor Matýsek ${ }^{5}$, \\ Łukasz Dudek ${ }^{1}$ and Kornel Pietrzak ${ }^{1}$ \\ 1 Department of Engineering and Informatics Systems, Faculty of Mechanical Engineering, \\ Koszalin University of Technology, Racławicka 15-17, PL 75-620 Koszalin, Poland; \\ tadeusz.hryniewicz@tu.koszalin.pl (T.H.); wojciech.kacalak@tu.koszalin.pl (W.K.); \\ katarzyna.tandecka@tu.koszalin.pl (K.T.); lukasz.dudek@tu.koszalin.pl (Ł.D.); \\ kornel.pietrzak@s.tu.koszalin.pl (K.P.) \\ 2 Department of Physics, Norwegian University of Science and Technology (NTNU), Realfagbygget E3-124 \\ Høgskoleringen 5, NO 7491 Trondheim, Norway; steinar.raaen@ntnu.no \\ 3 HORIBA FRANCE S.A.S., Avenue de la Vauve-Passage Jobin Yvon, CS 45002, 91120 Palaiseau, France; \\ sofia.gaiaschi@horiba.com (S.G.); patrick.chapon@horiba.com (P.C.) \\ 4 Hochschule Wismar-University of Applied Sciences Technology, Business and Design, \\ Faculty of Engineering, DE 23966 Wismar, Germany; winfried.malorny@hs-wismar.de \\ 5 Institute of Geological Engineering, Faculty of Mining and Geology, VŠB-Technical University of Ostrava, \\ 70833 Ostrava, Czech Republic; dalibor.matysek@vsb.cz \\ * Correspondence: rokosz@tu.koszalin.pl; Tel.: +48-94-3478354
}

Received: 15 May 2018; Accepted: 31 May 2018; Published: 2 June 2018

\begin{abstract}
In the paper, the effect of voltage increase (from $500 \mathrm{~V}_{\mathrm{DC}}$ up to $650 \mathrm{~V}_{\mathrm{DC}}$ ) on the structure and chemical composition of the porous coating on titanium made by Plasma Electrolytic Oxidation is presented. Phosphates-based coatings enriched with calcium, magnesium, zinc, and copper in electrolyte based on $1 \mathrm{~L}$ of $85 \%$ concentrated $\mathrm{H}_{3} \mathrm{PO}_{4}$, with additions of $\mathrm{Ca}\left(\mathrm{NO}_{3}\right)_{2} \cdot 4 \mathrm{H}_{2} \mathrm{O}$, and $\mathrm{Mg}\left(\mathrm{NO}_{3}\right)_{2} \cdot 6 \mathrm{H}_{2} \mathrm{O}$, and $\mathrm{Zn}\left(\mathrm{NO}_{3}\right)_{2} \cdot 6 \mathrm{H}_{2} \mathrm{O}$, and $\mathrm{Cu}\left(\mathrm{NO}_{3}\right)_{2} \cdot 3 \mathrm{H}_{2} \mathrm{O}$, are described. The morphology and chemical and phase composition are evaluated using SEM, EDS, XRD, XPS, GDOES, and CLSM. Based on these analyses, it was found that $\mathrm{PEO}$ coatings are porous and enriched with calcium, magnesium, zinc and copper. They consist mainly of the amorphous phase, which is more visible for higher voltages; this is correlated with an increase in the total PEO coating thickness (the higher the voltage, the thicker the PEO coating). However, for $650 \mathrm{~V}_{\mathrm{DC}}$, an amorphous phase and titanium substrate were also recorded, with a signal from $\mathrm{Ti}_{2} \mathrm{P}_{2} \mathrm{O}_{7}$ crystalline that was not observed for lower voltages. It was also found that all obtained coatings may be divided into three sub-layers, i.e., porous, semiporous, and transitional.
\end{abstract}

Keywords: Plasma Electrolytic Oxidation (PEO); Micro Arc Oxidation (MAO); titanium

\section{Introduction}

The electrochemical treatment which is known in the literature as Plasma Electrolytic Oxidation (PEO), Micro Arc Oxidation (MAO), or Spark Discharge Anodizing (SDA) may be used to form micro-porous coatings on lightweight metals, such as titanium [1], zirconium [2], tantalum [3], niobium [4], and titanium alloys (Ti6Al4V [5], Ti6Al7Nb [6], Ti-Nb-Zr-Sn [7], NiTi [8], Ti13Nb13Zr [9]. 
The porous coatings obtained with such a method are mostly used as biomaterials, and are enriched with calcium and phosphorus to form a structure similar to that of hydroxyapatite [10], which may be doped by the addition of bactericidal copper [11], as well as zinc [12] and magnesium [13], added in case of acceleration of wound healing. The PEO processes may be performed under DC [7], AC [14,15], and pulse regime [16,17], which yields coatings with different porosities and chemical compositions, and also with different coating thicknesses. In the case of titanium and its alloys, the electrolytes which are used are mostly aqueous solutions with additions of various salts, acids and hydroxides, as presented in Table 1.

Table 1. Examples of aqueous electrolytes used to PEO (Plasma Electrolytic Oxidation) treatment of titanium and its alloys.

\begin{tabular}{|c|c|}
\hline Electrolytes & Ref. \\
\hline sodium silicate $\left(\mathrm{Na}_{2} \mathrm{SiO}_{3}\right)$ with trisodium phosphate $\left(\mathrm{Na}_{3} \mathrm{PO}_{4}\right)$, and sodium aluminate $\left(\mathrm{NaAlO}_{2}\right)$ & [5] \\
\hline calcium hypophosphite $\mathrm{Ca}\left(\mathrm{H}_{2} \mathrm{PO}_{2}\right)_{2}$ with phosphoric acid $\mathrm{H}_{3} \mathrm{PO}_{4}$ & [9] \\
\hline $\begin{array}{l}\text { sodium phosphate monobasic monohydrate }\left(\mathrm{NaH}_{2} \mathrm{PO}_{4} \cdot \mathrm{H}_{2} \mathrm{O}\right) \text { with calcium acetate hydrate } \\
\left(\mathrm{Ca}\left(\mathrm{CH}_{3} \mathrm{COO}\right)_{2} \cdot \mathrm{H}_{2} \mathrm{O}\right) \text { and strontium hydroxide } 8 \text {-hydrate }\left(\mathrm{Sr}(\mathrm{OH})_{2} \cdot 8 \mathrm{H}_{2} \mathrm{O}\right)\end{array}$ & [18] \\
\hline 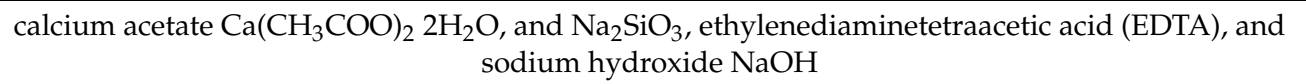 & [19] \\
\hline $\begin{array}{l}\text { tri-sodium orthophosphate }\left(\mathrm{Na}_{3} \mathrm{PO}_{4} \cdot 12 \mathrm{H}_{2} \mathrm{O}\right) \text { with potassium hydroxide }(\mathrm{KOH}) \text { and di-sodium tetra } \\
\text { borate }\left(\mathrm{Na}_{2} \mathrm{~B}_{4} \mathrm{O}_{7} \cdot 10 \mathrm{H}_{2} \mathrm{O}\right) \text {, and trisodium citrate dihydrate }\left(\mathrm{C}_{6} \mathrm{H}_{5} \mathrm{Na}_{3} \mathrm{O}_{7} \cdot 2 \mathrm{H}_{2} \mathrm{O}\right) \text {, and sodium meta } \\
\text { silicate nonahydrate }\left(\mathrm{Na}_{2} \mathrm{SiO}_{3} \cdot 9 \mathrm{H} 2 \mathrm{O}\right)\end{array}$ & [20] \\
\hline disodium phosphate $\left(\mathrm{Na}_{2} \mathrm{HPO}_{4}\right)$ & [21] \\
\hline ammonium sulfate solution $\left(\left(\mathrm{NH}_{4}\right)_{2} \mathrm{SO}_{4}\right)$ & [22] \\
\hline $\begin{array}{l}\text { sodium dihydrogen phosphate }\left(\mathrm{NaH}_{2} \mathrm{PO}_{4}\right) \text { with calcium acetate }\left(\mathrm{Ca}\left(\mathrm{CH}_{3} \mathrm{COO}\right)_{2}\right) \text { and strontium(II) } \\
\text { acetate }\left(\mathrm{Sr}\left(\mathrm{CH}_{3} \mathrm{COO}\right)_{2}\right)\end{array}$ & [23] \\
\hline sodium hydroxide $(\mathrm{NaOH})$ with sodium phytate $\left(\mathrm{Na}_{12} \mathrm{Phy}\right)$ & [24] \\
\hline sodium phosphate heptahydrate $\left(\mathrm{Na}_{2} \mathrm{HPO}_{4} \cdot 7 \mathrm{H}_{2} \mathrm{O}\right)$, with $\alpha-\mathrm{Al}_{2} \mathrm{O}_{3}$ and ketoconazole & [25] \\
\hline $\begin{array}{l}\text { trisodium phosphate }\left(\mathrm{Na}_{3} \mathrm{PO}_{4}\right) \text { with hydrated sodium borate }\left(\mathrm{Na}_{2} \mathrm{~B}_{4} \mathrm{O}_{7}\right) \text {, and sodium tungstate } \\
\qquad\left(\mathrm{Na}_{2} \mathrm{WO}_{4}\right)\end{array}$ & [26] \\
\hline $\begin{array}{c}\text { ethylenediaminetetraacetic acid (EDTA) with calcium }\left(\mathrm{Ca}\left(\mathrm{CH}_{3} \mathrm{COO}\right)_{2}\right), \mathrm{Ca}\left(\mathrm{H}_{2} \mathrm{PO}_{4}\right)_{2} \text {, sodium } \\
\text { hydroxide }(\mathrm{NaOH})\end{array}$ & [27] \\
\hline
\end{tabular}

It should be pointed out that, in the majority of the literature, the presence of titanium oxides in PEO coatings obtained on titanium in aqueous solutions is most often reported. However, Sowa et. al. [9] reported that it was also possible to obtain a PEO coating in aqueous solution, in which mostly phosphates were detected. In the present paper, the continuation of previous works [13], i.e., the characterization of PEO coatings formed in electrolytes containing the concentrated phosphoric acid $\left(\mathrm{H}_{3} \mathrm{PO}_{4}\right)$ with the addition of four nitrates $\left(\mathrm{Ca}\left(\mathrm{NO}_{3}\right)_{2} \cdot 4 \mathrm{H}_{2} \mathrm{O}, \mathrm{Mg}\left(\mathrm{NO}_{3}\right)_{2} \cdot 6 \mathrm{H}_{2} \mathrm{O}, \mathrm{Zn}\left(\mathrm{NO}_{3}\right)_{2} \cdot 6 \mathrm{H}_{2} \mathrm{O}\right.$, $\left.\mathrm{Cu}\left(\mathrm{NO}_{3}\right)_{2} \cdot 3 \mathrm{H}_{2} \mathrm{O}\right)$, will be presented. The studies already carried out by the authors have shown that it is possible to obtain porous PEO coatings which are enriched only with copper [28] or calcium [29]. In addition, in reference to [13], new coatings obtained in electrolyte contacting two nitrates $\left(\mathrm{Zn}\left(\mathrm{NO}_{3}\right)_{2} \cdot 6 \mathrm{H}_{2} \mathrm{O}, \mathrm{Mg}\left(\mathrm{NO}_{3}\right)_{2} \cdot 6 \mathrm{H}_{2} \mathrm{O}\right)$ were presented. It was found that their $\mathrm{Zn} / \mathrm{P}$ and $\mathrm{Mg} / \mathrm{P}$ ratios depend on the $\mathrm{PEO}$ voltage, and that the $\mathrm{Zn} / \mathrm{P}$ ratio increases linearly with voltage; in contrast, the $\mathrm{Mg} / \mathrm{P}$ ratio it is a constant function. That information led the authors to consider the possibility of creating new porous coatings enriched in more than two elements, and of determining the relation between elements originating from electrolyte $(\mathrm{Ca}, \mathrm{Cu}, \mathrm{Mg}, \mathrm{Zn}, \mathrm{P})$. However, it was not possible to predict the composition of that coating based on the chemical composition of the electrolyte without experimental studies. Moreover, in the available literature there was no information on how such a porous coating would look, nor what its chemical composition would be, or the relation between each element. Therefore, the main goal of this paper is to present the results related to new porous PEO 
coatings on titanium, which may be used as a transition layer between titanium biomaterial and tissue, as well as a porous substrate for catalysts. It should be also noted that the selection of elements, such as calcium, phosphorus, magnesium, zinc, and copper for new biocompatible coatings is based upon the need to create a hydroxyapatite-like structure $\left(\mathrm{Ca}_{5}\left(\mathrm{PO}_{4}\right)_{3}(\mathrm{OH})\right)$, in which the $\mathrm{Ca}^{2+}$ ions can be replaced by antibacterial zinc $\mathrm{Zn}^{2+}$ and copper $\mathrm{Cu}^{2+}$ ions and by $\mathrm{Mg}^{2+}$ ions, which improve the healing of wounds. All the elements should be built into the porous structure in its entire volume; this will allow a slow release of selected ions into the body after surgery. On the other hand it should be pointed out that the obtained coatings, with developed surface stereometry, may be used for catalyst creation.

\section{Materials and Methods}

Titanium samples with dimensions of $10 \mathrm{~mm} \times 10 \mathrm{~mm} \times 2 \mathrm{~mm}$ were treated by Plasma Electrolytic Oxidation, at voltages of $500 \mathrm{~V}_{\mathrm{DC}}, 575 \mathrm{~V}_{\mathrm{DC}}$ and $650 \mathrm{~V}_{\mathrm{DC}}$, with the use of a commercial DC power supply (PWR 1600H, KIKUSUI Electronics Corporation, Yokohama, Japan). The electrolyte composition was the following: $1 \mathrm{~L}$ of $85 \% \mathrm{H}_{3} \mathrm{PO}_{4}, 125 \mathrm{~g} \mathrm{Ca}\left(\mathrm{NO}_{3}\right)_{2} \cdot 4 \mathrm{H}_{2} \mathrm{O}, 125 \mathrm{~g} \mathrm{Mg}\left(\mathrm{NO}_{3}\right)_{2} \cdot 6 \mathrm{H}_{2} \mathrm{O}, 125 \mathrm{~g}$ $\mathrm{Zn}\left(\mathrm{NO}_{3}\right)_{2} \cdot 6 \mathrm{H}_{2} \mathrm{O}$, and $125 \mathrm{~g} \mathrm{Cu}\left(\mathrm{NO}_{3}\right)_{2} \cdot 3 \mathrm{H}_{2} \mathrm{O}$. The surface morphology was recorded by a scanning electron microscope (SEM) Quanta 250 FEI (Field Electron and Iron Company, Hillsboro, OR, USA) as well as an Energy-dispersive X-ray spectroscopy (EDS) (EDS Silicon Drift Detectors: Keith Thompson, Thermo Fisher Scientific, Madison, WI, USA). The depth profiles of PEO coatings were performed by Glow Discharge Optical Emission Spectroscopy (GDOES) [30] measurements, using a Horiba Scientific GD Profiler 2 instrument (HORIBA Scientific, Palaiseau, France) using a radio frequency (RF) pulsed source $(700 \mathrm{~Pa}, 40 \mathrm{~W}, 3000 \mathrm{~Hz}$ ) with an anode diameter of $4 \mathrm{~mm}$ (analyzed surface area equal to $12.56 \mathrm{~mm}^{2}$ ). The structure was studied by Powder X-ray diffraction (XRD) using a Bruker-AXS D8 Advance instrument (BRUKER Corporation, Billerica, MA, USA), with the $2 \theta / \theta$ geometry using a LynxEye position-sensitive detector (radiation $\mathrm{CuK} \alpha / \mathrm{Ni}$ filter, $40 \mathrm{kV}, 40 \mathrm{~mA}, 0.0142 \theta$, interval of $0.25 \mathrm{~s}$, BRUKER Corporation, Billerica, MA, USA). The quantitative and qualitative chemical compositions of the top $10 \mathrm{~nm}$ of PEO coatings were studied by X-ray photoelectron spectroscopy (XPS); measurements were made using SCIENCE SES 2002 instrument (SCIENTA AB, ScientaOmicron, Uppsala, Sweden) with a monochromatic (Gammadata-Scienta) Al K(alpha) ( $h v=1486.6 \mathrm{eV}) \mathrm{X}$-ray source $(18.7 \mathrm{~mA}, 13.02 \mathrm{kV})$. All studies were carried out on a surface of about $3 \mathrm{~mm}^{2}$, with a pass energy of $500 \mathrm{eV}$ (energy step $0.2 \mathrm{eV}$ and step time $200 \mathrm{~ms}$ ) with a base pressure of about $6 \cdot 10^{-8} \mathrm{~Pa}$. The XPS spectra were processed in CasaXPS sotware [31] and interpreted based on NIST X-ray Photoelectron Spectroscopy Database [32] and XPS handbook [33]. SEM, EDS, XPS and GDOES measurement techniques, which have been used to characterize the PEO coatings, are described in detail in the references [13]. The surface topography of PEO coatings was evaluated by confocal laser scanning microscopy (CLSM), using a LEXT OLS4000 3D Laser Confocal Microscope (Olympus, Japan). A measuring field of $244 \mu \mathrm{m} \times 244 \mu \mathrm{m}$ was scanned in three places on the surface coating. To obtain the measuring field, 4 scans were taken and then combined. Surface roughness was presented in 3D surface images. The following 3D parameters were calculated to obtain surface roughness: $(S a, S z)$ (ISO 25178), where $S a$ it is arithmetical mean height (mean surface roughness), and $S z$ it is maximum height (height between the highest peak and the deepest valley). For statistical data processing, the descriptive statistics (mean, standard deviation, first quartile, third quartile), and rank score test at the level of significance $\alpha=0.05$, were used.

\section{Results and Discussion}

In Figure 1, the SEM images of porous coatings obtained on CP Titanium Grade 2 after PEO treatment at voltages of $500 \mathrm{~V}_{\mathrm{DC}}, 575 \mathrm{~V}_{\mathrm{DC}}$ and $650 \mathrm{~V}_{\mathrm{DC}}$, are presented. It can be observed that the voltage increase results in a change in surface morphology, as well as pore shapes and sharpness. Due to the fact that, on the basis of SEM images, it was not possible to differentiate the surfaces of the obtained PEO coatings, 3D roughness parameters were used to describe them, and are presented in Table 2. 
Table 2. Statistical descriptions of 3D roughness parameters ( $S a$ and $S z)$ in micrometers.

\begin{tabular}{cccccc}
\hline 3D Roughness Parameter & Voltage & Mean & Stand. Dev. & First Quartile & Third Quartile \\
\hline \multirow{3}{*}{$S a$} & $500 \mathrm{~V}_{\mathrm{DC}}$ & 1.74 & 0.29 & 1.44 & 2.02 \\
& $575 \mathrm{~V}_{\mathrm{DC}}$ & 2.08 & 0.15 & 1.92 & 2.22 \\
& $650 \mathrm{~V}_{\mathrm{DC}}$ & 3.50 & 0.06 & 3.45 & 3.57 \\
\hline \multirow{3}{*}{$S z$} & $500 \mathrm{~V}_{\mathrm{DC}}$ & 31.61 & 8.39 & 24.24 & 40.75 \\
& $575 \mathrm{~V}_{\mathrm{DC}}$ & 25.33 & 2.72 & 22.20 & 27.15 \\
& $650 \mathrm{~V}_{\mathrm{DC}}$ & 47.25 & 1.03 & 46.18 & 48.25 \\
\hline
\end{tabular}

Based on parameters $S a$ (arithmetical mean height) and $S z$ (height between the highest peak and the deepest valley), it was possible to conclude that the smallest roughness was found for PEO coatings obtained at $500 \mathrm{~V}_{\mathrm{DC}}(S a=1.74 \pm 0.29 \mu \mathrm{m}, S z=31.61 \pm 8.39 \mu \mathrm{m})$ and $575 \mathrm{~V}_{\mathrm{DC}}(S a=2.08 \pm 0.15 \mu \mathrm{m}$, $S z=25.33 \pm 2.72 \mu \mathrm{m})$. By increasing the PEO voltage to $650 \mathrm{~V}_{\mathrm{DC}}$, it was noted that the two parameters, $S a$ and $S z$, increased by about $50 \%$ relative to those ones associated with PEO coatings formed at $500 \mathrm{~V}_{\mathrm{DC}}$, and equal to $S a=3.50 \pm 0.06 \mu \mathrm{m}, S z=47.25 \pm 1.03 \mu \mathrm{m}$, respectively. It should be noted that the quantitative description by $3 \mathrm{D}$ roughness parameters ( $S a$ and $S z$ ) matches the SEM images presented in Figure 1. The external porosity, which may be described by those parameters, indicates that the larger the pore diameter, the higher the roughness parameters. Based on that notion, it may be concluded that coatings obtained at $500 \mathrm{~V}_{\mathrm{DC}}$ and $575 \mathrm{~V}_{\mathrm{DC}}$ have similar porosity; this was confirmed by a statistical rank score test at the level of significance $\alpha=0.05$, while those formed at $650 \mathrm{~V}_{\mathrm{DC}}$ have more open, volcanoes-like pores which are very clearly visible at the smallest magnification $(500 \times)$ in Figure 1, and were confirmed by the same test.
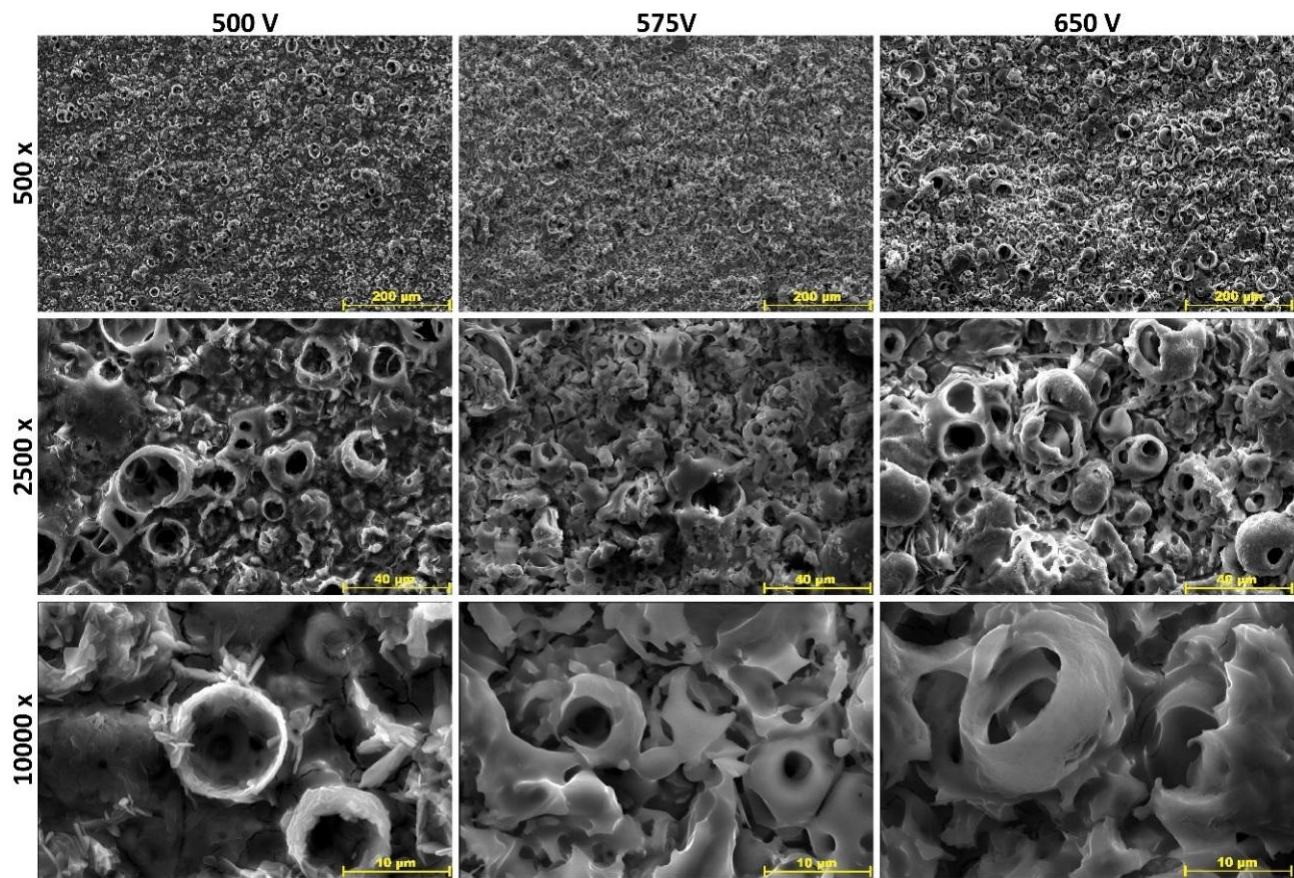

Figure 1. SEM images of coatings formed on Titanium after PEO process at voltages $500 \mathrm{~V}_{\mathrm{DC}}, 575 \mathrm{~V}_{\mathrm{DC}}$, $650 \mathrm{~V}_{\mathrm{DC}}$ in $1 \mathrm{~L}$ of $85 \% \mathrm{H}_{3} \mathrm{PO}_{4}$ with additions of $125 \mathrm{Ca}\left(\mathrm{NO}_{3}\right)_{2} \cdot 4 \mathrm{H}_{2} \mathrm{O}, 125 \mathrm{~g} \mathrm{Mg}\left(\mathrm{NO}_{3}\right)_{2} \cdot 6 \mathrm{H}_{2} \mathrm{O}, 125 \mathrm{~g}$ $\mathrm{Zn}\left(\mathrm{NO}_{3}\right)_{2} \cdot 6 \mathrm{H}_{2} \mathrm{O}$, and $125 \mathrm{~g} \mathrm{Cu}\left(\mathrm{NO}_{3}\right)_{2} \cdot 3 \mathrm{H}_{2} \mathrm{O}$ at magnifications 500, 1000, 2500, 5000, and 10000 times.

On the basis of EDS spectra, recorded at $500 \times$ magnification, the atomic concentrations of $\mathrm{Ca}, \mathrm{Mg}$, $\mathrm{Zn}, \mathrm{Cu}$, and $\mathrm{P}$ were used to calculate metals-to-phosphorus atomic ratios, with the results presented in Figure 2 and Table 3. Based on these results, it can be observed that $\mathrm{Mg} / \mathrm{P}, \mathrm{Zn} / \mathrm{P}, \mathrm{Cu} / \mathrm{P}$, and $\mathrm{M} / \mathrm{P}$ 
values have a positive correlation with voltage. The case of $\mathrm{Ca} / \mathrm{P}$ values to voltage relation indicates the different mechanisms of calcium compounds in the layer. Considering the standard deviation values of the metal-to-phosphorus ratio, it can be concluded that the most repeatable conditions of the $\mathrm{PEO}$ process are at around $575 \mathrm{~V}_{\mathrm{DC}}$.

Table 3. Statistical descriptions of $\mathrm{Ca} / \mathrm{P}, \mathrm{Mg} / \mathrm{P}, \mathrm{Zn} / \mathrm{P}, \mathrm{Cu} / \mathrm{P}, \mathrm{M} / \mathrm{P}$ ratios based on atomic percent $(\mathrm{M}=$ $\mathrm{Ca}+\mathrm{Mg}+\mathrm{Zn}+\mathrm{Cu})$.

\begin{tabular}{lccccc}
\hline Ratios & Voltage & Mean & Stand. Dev. & First quartile & Third Quartile \\
\hline \multirow{3}{*}{$\mathrm{Ca} / \mathrm{P}$} & $500 \mathrm{~V}_{\mathrm{DC}}$ & 0.070 & 0.009 & 0.062 & 0.079 \\
& $575 \mathrm{~V}_{\mathrm{DC}}$ & 0.054 & 0.002 & 0.053 & 0.056 \\
& $650 \mathrm{~V}_{\mathrm{DC}}$ & 0.089 & 0.011 & 0.077 & 0.098 \\
\hline \multirow{3}{*}{$\mathrm{Mg} / \mathrm{P}$} & $500 \mathrm{~V}_{\mathrm{DC}}$ & 0.037 & 0.002 & 0.035 & 0.038 \\
& $575 \mathrm{~V}_{\mathrm{DC}}$ & 0.044 & 0.002 & 0.042 & 0.046 \\
& $650 \mathrm{~V}_{\mathrm{DC}}$ & 0.045 & 0.001 & 0.043 & 0.046 \\
\hline \multirow{3}{*}{$\mathrm{n} / \mathrm{P}$} & $500 \mathrm{~V}_{\mathrm{DC}}$ & 0.034 & 0.006 & 0.029 & 0.039 \\
& $575 \mathrm{~V}_{\mathrm{DC}}$ & 0.045 & 0.003 & 0.042 & 0.049 \\
& $650 \mathrm{~V}_{\mathrm{DC}}$ & 0.048 & 0.005 & 0.043 & 0.052 \\
$\mathrm{Cu} / \mathrm{P}$ & $500 \mathrm{~V}_{\mathrm{DC}}$ & 0.032 & 0.002 & 0.030 & 0.033 \\
& $575 \mathrm{~V}_{\mathrm{DC}}$ & 0.037 & 0.003 & 0.033 & 0.040 \\
& $650 \mathrm{~V}_{\mathrm{DC}}$ & 0.043 & 0.011 & 0.036 & 0.052 \\
\hline \multirow{3}{*}{$\mathrm{M} / \mathrm{P}$} & $500 \mathrm{~V}_{\mathrm{DC}}$ & 0.172 & 0.012 & 0.162 & 0.184 \\
& $575 \mathrm{~V}_{\mathrm{DC}}$ & 0.180 & 0.005 & 0.178 & 0.184 \\
& $650 \mathrm{~V}_{\mathrm{DC}}$ & 0.224 & 0.014 & 0.215 & 0.236 \\
\hline
\end{tabular}

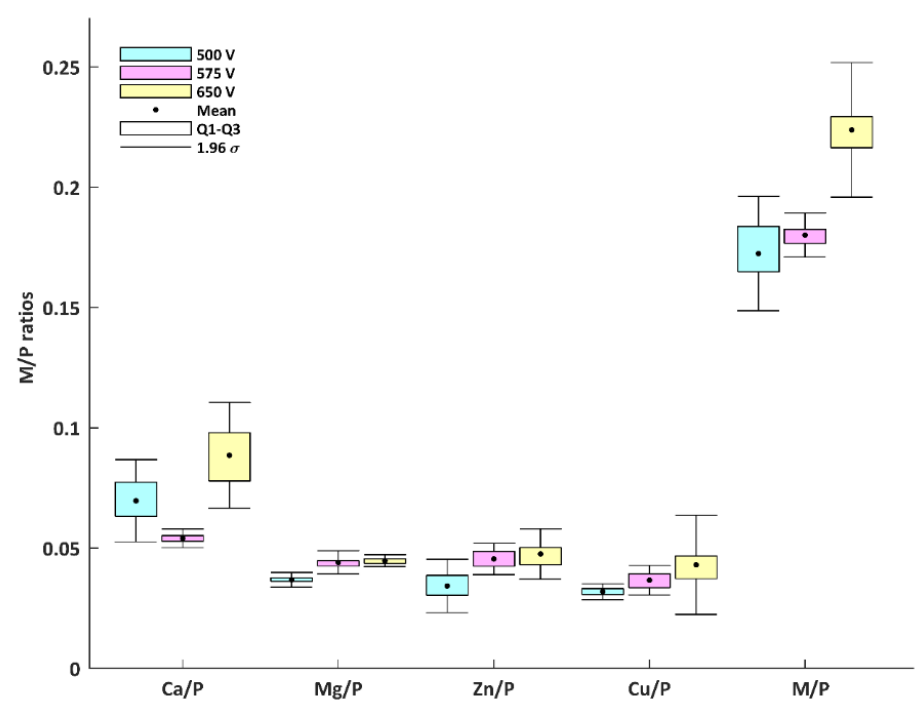

Figure 2. $\mathrm{EDS}$ results as $\mathrm{Ca} / \mathrm{P}, \mathrm{Mg} / \mathrm{P}, \mathrm{Zn} / \mathrm{P}, \mathrm{Cu} / \mathrm{P}$ and $\mathrm{M} / \mathrm{P}(\mathrm{M}=\mathrm{Ca}+\mathrm{Mg}+\mathrm{Zn}+\mathrm{Cu})$ ratios measured for coatings formed on CP Titanium Grade 2 after PEO process at the voltages $500 \mathrm{~V}_{\mathrm{DC}}, 575 \mathrm{~V}_{\mathrm{DC}}$, $650 \mathrm{~V}_{\mathrm{DC}}$ in $1 \mathrm{~L}$ of $85 \% \mathrm{H}_{3} \mathrm{PO}_{4}$ with additions of $125 \mathrm{Ca}\left(\mathrm{NO}_{3}\right)_{2} \cdot 4 \mathrm{H}_{2} \mathrm{O}, 125 \mathrm{~g} \mathrm{Mg}\left(\mathrm{NO}_{3}\right)_{2} \cdot 6 \mathrm{H}_{2} \mathrm{O}, 125 \mathrm{~g}$ $\mathrm{Zn}\left(\mathrm{NO}_{3}\right)_{2} \cdot 6 \mathrm{H}_{2} \mathrm{O}$, and $125 \mathrm{~g} \mathrm{Cu}\left(\mathrm{NO}_{3}\right)_{2} \cdot 3 \mathrm{H}_{2} \mathrm{O}$.

In Figure 3, the XPS spectra of PEO coating formed on Titanium at $575 \mathrm{~V}_{\mathrm{DC}}$ are presented. Based on the registered peaks, it can be concluded that the top $10 \mathrm{~nm}$ layer of the PEO coating is enriched with calcium, magnesium, zinc, copper, and titanium, as well as phosphorus, oxygen, and nitrogen. It should be also pointed out that carbon bound with oxygen, as well as the nitrogen-oxygen compounds, should be treated as organic contaminants, which mainly originate from the air or from cleaning. The binding energies of $134.4 \mathrm{eV}(\mathrm{P} 2 \mathrm{p})$ and $531.2 \mathrm{eV}(\mathrm{O} 1 \mathrm{~s})$ may be interpreted as $\mathrm{PO}_{4}{ }^{3-}$, or/and $\mathrm{HPO}_{4}{ }^{2-}$, or /and 
$\mathrm{H}_{2} \mathrm{PO}_{4}{ }^{-}$or / and $\mathrm{P}_{2} \mathrm{O}_{7}{ }^{4-}$ groups. The $\mathrm{Cu} 2 \mathrm{p}$ spectra with two main maxima $(347.9 \mathrm{eV}, 351 \mathrm{eV})$, as well as the satellite peaks existing in the range from $939 \mathrm{eV}$ up to $947 \mathrm{eV}$ as well as $566.8 \mathrm{eV}(\mathrm{Cu} \mathrm{LMM})$, may be interpreted as $\mathrm{Cu}^{+}$and $\mathrm{Cu}^{2+}$, while the presence of $\mathrm{Ca}^{2+}$ is demonstrated by the binding energies which are equal to $347.9 \mathrm{eV}$ and $351.4 \mathrm{eV}$. The binding energies at $497.9 \mathrm{eV}$ (Zn LMM), $500.4 \mathrm{eV}$ ( $\mathrm{Zn} \mathrm{LMM),} \mathrm{and} 1022.4 \mathrm{eV}$ ( $\mathrm{Zn} 2 \mathrm{p}$ ) may suggest the presence of $\mathrm{Zn}^{2+}$ in the PEO coating, whereas those equal to $50.6 \mathrm{eV}(\mathrm{Mg} 2 \mathrm{p}), 89.3 \mathrm{eV}$ (Mg 2s), $306.8 \mathrm{eV}$ (Mg KLL), indicate the presence of $\mathrm{Mg}^{2+}$. The biding energy of titanium Ti $2 \mathrm{p}_{3 / 2}$ is shifted to $460.4 \mathrm{eV}$. This can be interpreted as a sign of the presence of $\mathrm{Ti}^{4+}$ in chemical compounds within $\mathrm{Ca}^{2+}, \mathrm{Zn}^{2+}, \mathrm{Mg}^{2+}, \mathrm{Cu}^{2+}$, and $\mathrm{PO}_{4}{ }^{3-}$, or $/$ and $\mathrm{HPO}_{4}{ }^{2-}$, or/and $\mathrm{H}_{2} \mathrm{PO}_{4}{ }^{-}$or/and $\mathrm{P}_{2} \mathrm{O}_{7}{ }^{4-}$. Based on quantitative analysis, it may be concluded that in the top $10 \mathrm{~nm}$ of PEO coatings, Ca:Mg: $\mathrm{Zn}: \mathrm{Cu}$ ratios are equal to 16:29:1:1, 2:14:1:1, 6:17:1:1 for $500 \mathrm{~V}_{\mathrm{DC}}$, $575 \mathrm{~V}_{\mathrm{DC}}, 650 \mathrm{~V}_{\mathrm{DC}}$, respectively. Based on these results, it may be concluded that the probability of calcium and magnesium incorporation into the structure is the highest, while for zinc and copper, the smallest, remaining constant in the function of voltage. The analysis of $\mathrm{Ca} / \mathrm{P}, \mathrm{Mg} / \mathrm{P}, \mathrm{Zn} / \mathrm{P}, \mathrm{Cu} / \mathrm{P}$, $\mathrm{Ti} / \mathrm{P}$, and $\mathrm{M} / \mathrm{P}$ ratios allows us to conclude that a voltage increase, from $500 \mathrm{~V}_{\mathrm{DC}}$ up to $650 \mathrm{~V}_{\mathrm{DC}}$, results in an increase in the $\mathrm{Ca} / \mathrm{P}$ (from 0.033 up to 0.059 ) and $\mathrm{Ti} / \mathrm{P}$ (from 0.051 up to 0.119 ) ratios, while for other ratios, i.e., $\mathrm{Mg} / \mathrm{P}, \mathrm{Zn} / \mathrm{P}, \mathrm{Cu} / \mathrm{P}$, and $\mathrm{M} / \mathrm{P}$, the maxima equaling $0.251,0.018,0.018$, and 0.322 , respectively, for $575 \mathrm{~V}_{\mathrm{DC}}$, were determined. Considering the fact that the amount of copper and zinc compounds in coating structure should be high enough to have antibacterial properties in the case of surgical treatment, it should be suitable for use in anodic oxidation, with a voltage of $575 \mathrm{~V}_{\mathrm{DC}}$.

Figures 4 and 5 present the GDOES profile of calcium, copper, magnesium, zinc, and phosphorus, oxygen, hydrogen, and titanium, respectively, for PEO coatings. Based on these results, it is possible to conclude that the PEO coatings may be described by a three-sub-layer model. The first porous and top sub-layers are enriched with phosphorus, oxygen, calcium, copper, magnesium, and zinc. However, it should be noted that the maxima of signals in that sub-layer may be partly related to plasma inflammation and organic contaminations from the air or/and cleaning process. These are mainly registered for phosphorus $(178 \mathrm{~nm})$, as well as oxygen $(130 \mathrm{~nm})$ and hydrogen $(122 \mathrm{~nm})$ signals, which may be a part of structure (coating matrix) containing the phosphates and hydrogen phosphates enriched in calcium, magnesium, zinc, and copper, whose signals are much weaker in this range. In the second sub-layer, which is semiporous with nested finer pores in the pores, a plateau was observed for all GDOES signals. In that sublayer, the amount of chemical components originating from the electrolyte (calcium, magnesium, zinc, and copper) are stable; this is especially important in the case of biomaterials, because the possibility of tissue growing into the porosity of PEO coating during healing after surgery. It should therefore be protected from bacteria, which is associated with copper and zinc ions. In addition, calcium and phosphorus form the hydroxyapatite-like structure, which should be acceptable for tissue, and magnesium as an accelerator of wound healing. In places in the GDOES signals, where local maxima of calcium, copper, magnesium, zinc, and phosphorus are observed, the third transition sub-layer, in which increasing the levels of titanium and decreasing those of phosphorus, oxygen, calcium, copper, magnesium, and zinc are observed, has its beginning. Moreover, maxima in the hydrogen signals, which are in the middle of this sub-layer, should be treated as the end of the porosity of the coating. Based on the GDOES spectra, one can infer that an increase in the PEO voltage results in an increase of the coating thickness, which may be expressed in sputtering times in seconds. Therefore, all the sublayer thicknesses depend on PEO voltage. The top one has thicknesses of $200 \mathrm{~s}, 300 \mathrm{~s}$, and $400 \mathrm{~s}$ of sputtering time for $500 \mathrm{~V}_{\mathrm{DC}}, 575 \mathrm{~V}_{\mathrm{DC}}, 650 \mathrm{~V}_{\mathrm{DC}}$, respectively, while the thickness of the second one is in the range of $1200 \mathrm{~s}\left(500 \mathrm{~V}_{\mathrm{DC}}\right)$ up to $2900 \mathrm{~s}\left(650 \mathrm{~V}_{\mathrm{DC}}\right)$ of sputtering time. For the thickness of the third, the transition layer increases with an increase in voltage from $1100 \mathrm{~s}\left(500 \mathrm{~V}_{\mathrm{DC}}\right)$ up to $2000 \mathrm{~s}\left(650 \mathrm{~V}_{\mathrm{DC}}\right)$ of sputtering time. In addition, it was observed that the thickness of the first sub-layer may be described by a linear trend in function of PEO voltage, i.e., 1.33 U-66.67, while the second and the third ones follow the equations: 11.33 U-4550 and 6 U-1950, respectively, where $U$ is in the range from $500 V_{D C}$ to $650 V_{D C}$. 

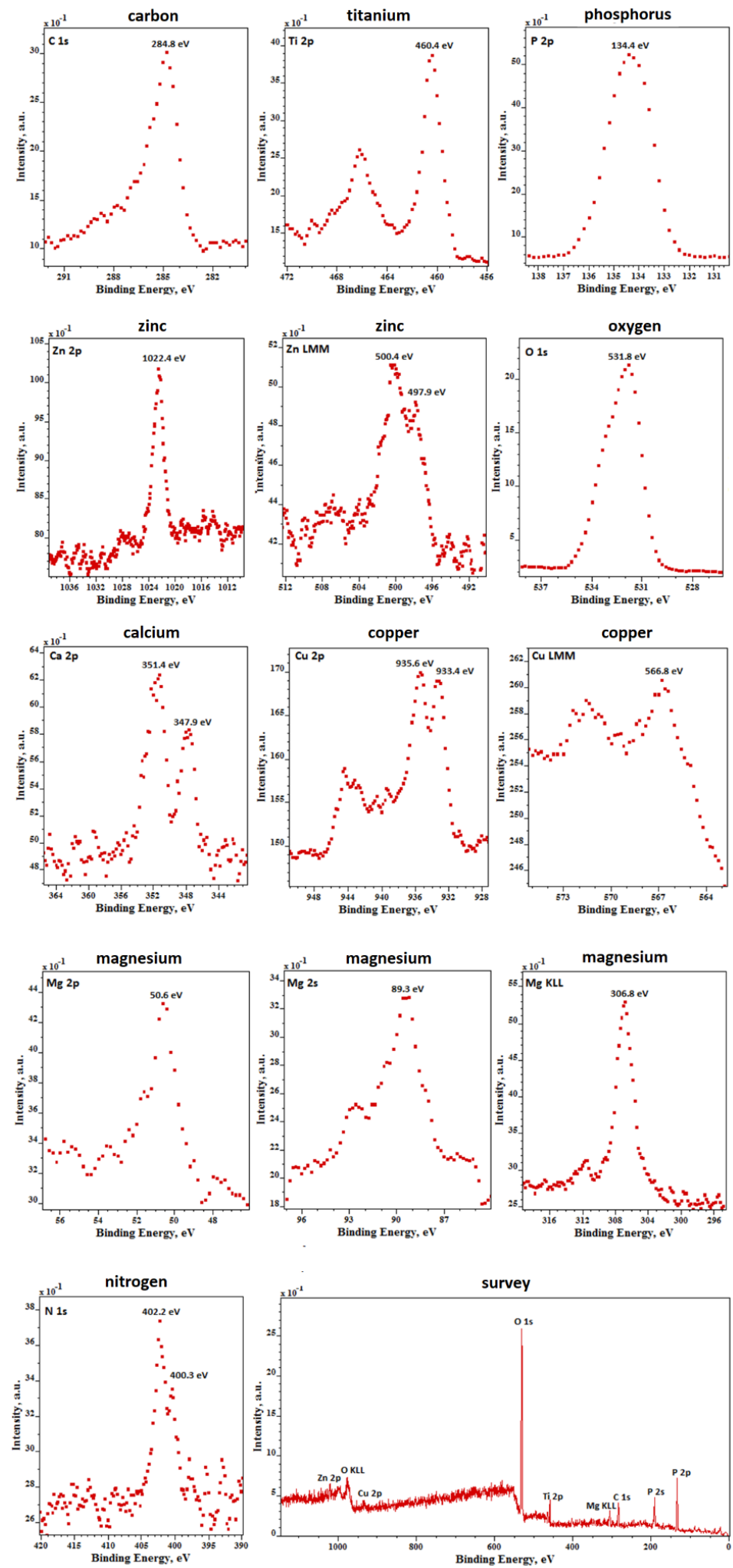

Figure 3. XPS spectra of coatings formed on CP Titanium Grade 2 after PEO process at voltage $575 \mathrm{~V}_{\mathrm{DC}}$ in $1 \mathrm{~L}$ of $85 \% \mathrm{H}_{3} \mathrm{PO}_{4}$ with additions of $125 \mathrm{~g} \mathrm{Ca}\left(\mathrm{NO}_{3}\right)_{2} \cdot 4 \mathrm{H}_{2} \mathrm{O}, 125 \mathrm{~g} \mathrm{Mg}\left(\mathrm{NO}_{3}\right)_{2} \cdot 6 \mathrm{H}_{2} \mathrm{O}, 125 \mathrm{~g}$ $\mathrm{Zn}\left(\mathrm{NO}_{3}\right)_{2} \cdot 6 \mathrm{H}_{2} \mathrm{O}$, and $125 \mathrm{~g} \mathrm{Cu}\left(\mathrm{NO}_{3}\right)_{2} \cdot 3 \mathrm{H}_{2} \mathrm{O}$. 

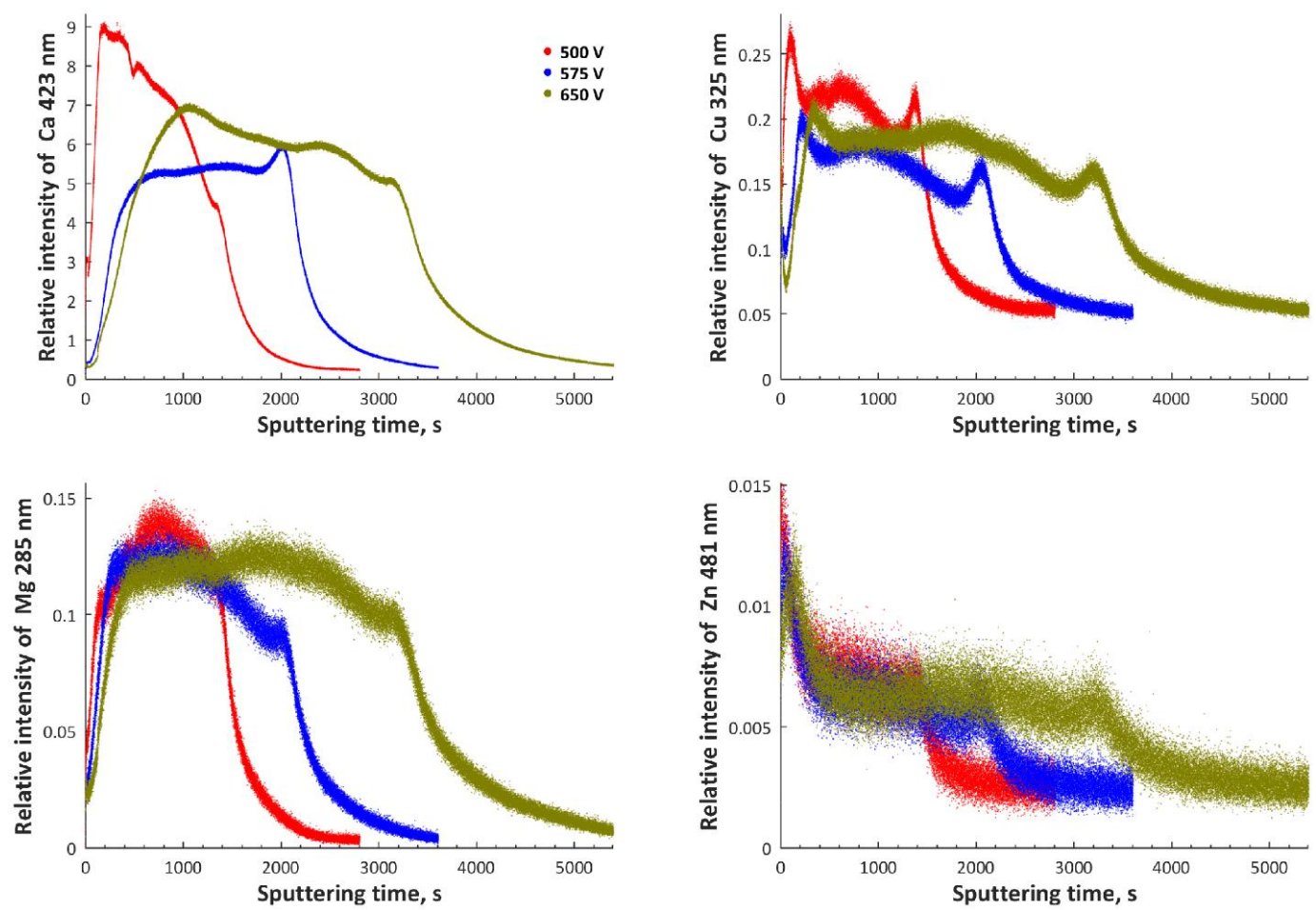

Figure 4. GDEOS (Glow Discharge Optical Emission Spectroscopy) signals of calcium (Ca), magnesium $(\mathrm{Mg})$, copper $(\mathrm{Cu})$ and zinc $(\mathrm{Zn})$ of coatings formed on CP Titanium Grade 2 after PEO process at voltages $500 \mathrm{~V}_{\mathrm{DC}}, 575 \mathrm{~V}_{\mathrm{DC}}, 650 \mathrm{~V}_{\mathrm{DC}}$, in $1 \mathrm{~L}$ of $85 \% \mathrm{H}_{3} \mathrm{PO}_{4}$ with the additions of $125 \mathrm{~g} \mathrm{Ca}\left(\mathrm{NO}_{3}\right)_{2} \cdot 4 \mathrm{H}_{2} \mathrm{O}$, $125 \mathrm{~g} \mathrm{Mg}\left(\mathrm{NO}_{3}\right)_{2} \cdot 6 \mathrm{H}_{2} \mathrm{O}, 125 \mathrm{~g} \mathrm{Zn}\left(\mathrm{NO}_{3}\right)_{2} \cdot 6 \mathrm{H}_{2} \mathrm{O}$, and $125 \mathrm{~g} \mathrm{Cu}\left(\mathrm{NO}_{3}\right)_{2} \cdot 3 \mathrm{H}_{2} \mathrm{O}$.
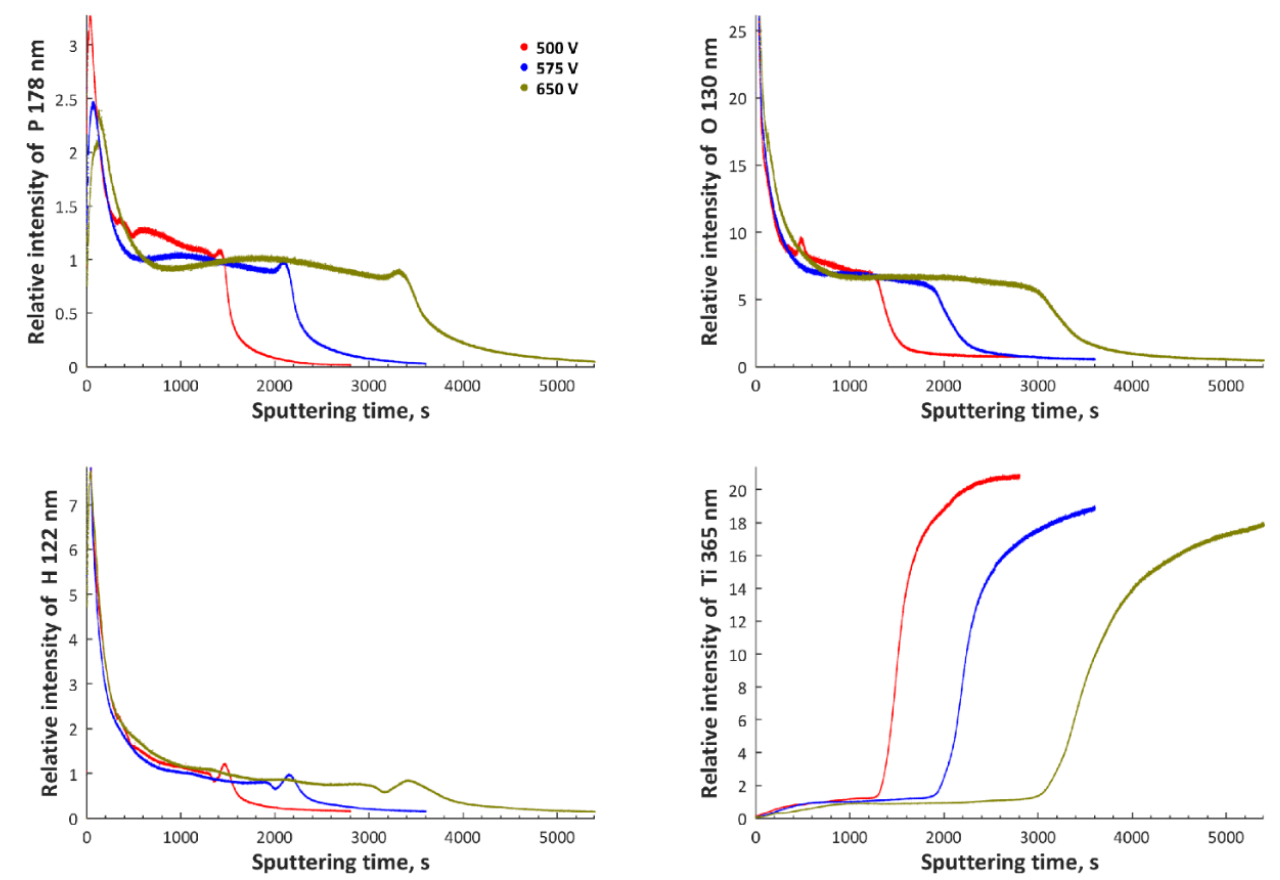

Figure 5. GDEOS signals of phosphorus $(\mathrm{P})$, oxygen $(\mathrm{O})$, hydrogen $(\mathrm{H})$ and titanium $(\mathrm{Ti})$ of coatings formed on CP Titanium Grade 2 after PEO process at voltages $500 \mathrm{~V}_{\mathrm{DC}}, 575 \mathrm{~V}_{\mathrm{DC}}, 650 \mathrm{~V}_{\mathrm{DC}}$, in $1 \mathrm{~L}$ of $85 \% \mathrm{H}_{3} \mathrm{PO}_{4}$ with the additions of $125 \mathrm{~g} \mathrm{Ca}\left(\mathrm{NO}_{3}\right)_{2} \cdot 4 \mathrm{H}_{2} \mathrm{O}, 125 \mathrm{~g} \mathrm{Mg}\left(\mathrm{NO}_{3}\right)_{2} \cdot 6 \mathrm{H}_{2} \mathrm{O}, 125 \mathrm{~g} \mathrm{Zn}\left(\mathrm{NO}_{3}\right)_{2} \cdot 6 \mathrm{H}_{2} \mathrm{O}$, and $125 \mathrm{~g} \mathrm{Cu}\left(\mathrm{NO}_{3}\right)_{2} \cdot 3 \mathrm{H}_{2} \mathrm{O}$. 
The phase composition of the PEO samples was studied by XRD, and the results are presented in Figure 6. These results show that, beyond the titanium signal coming from the substrate, the amorphous layer can be also identified. It should be pointed out that the higher the voltage, the higher the amorphous phase; this is due to an increase in the coating thickness. However, in the case of the PEO coating obtained at $650 \mathrm{~V}_{\mathrm{DC}}$, in addition to the amorphous phase, diffraction peaks due to the presence of $\mathrm{Ti}_{2} \mathrm{P}_{2} \mathrm{O}_{7}$ crystals, can be observed.
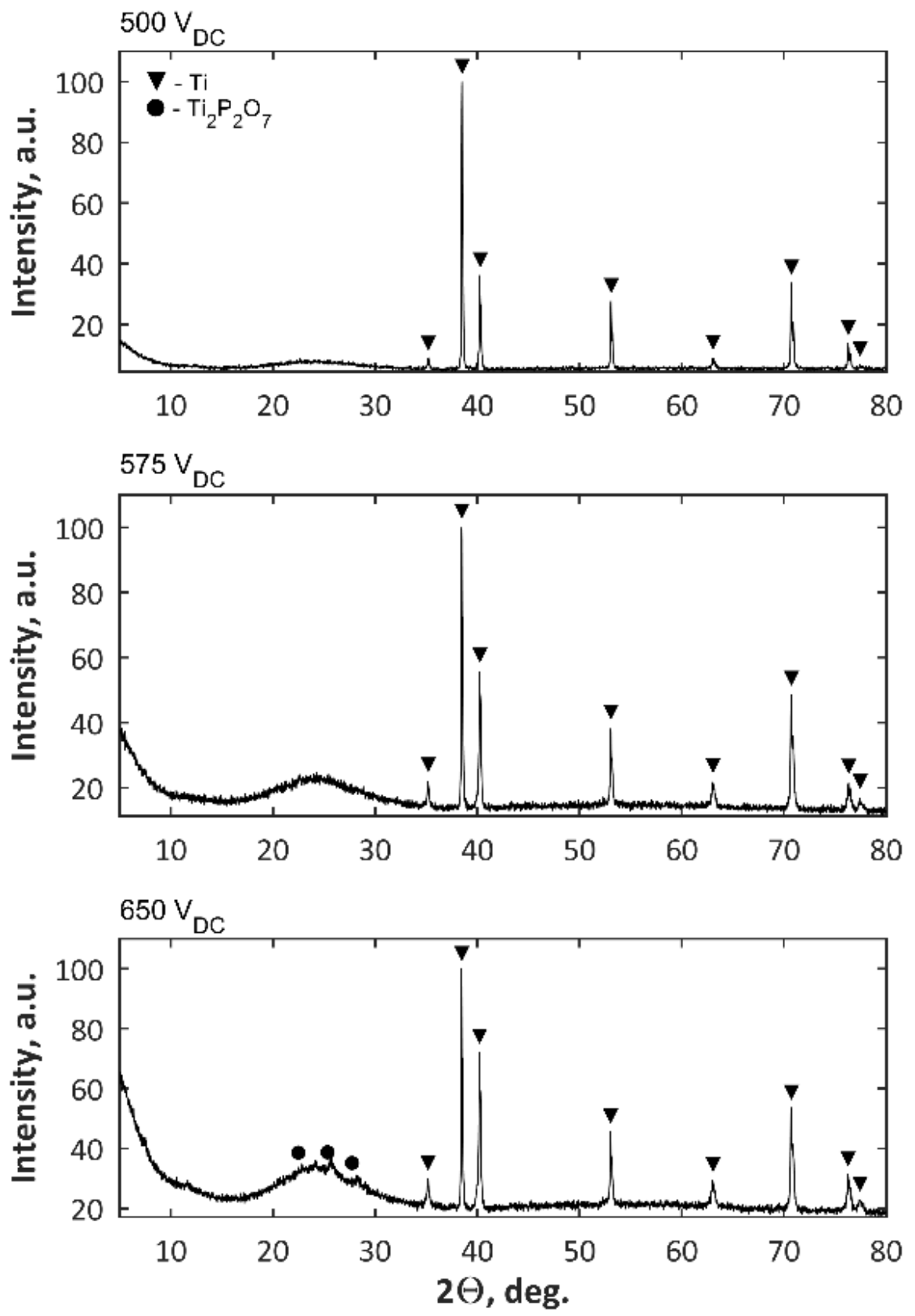

Figure 6. XRD (X-ray Diffraction) patterns of coatings formed on CP Titanium Grade 2 after PEO process at voltages $500 \mathrm{~V}_{\mathrm{DC}}, 575 \mathrm{~V}_{\mathrm{DC}}, 650 \mathrm{~V}_{\mathrm{DC}}$, in $1 \mathrm{~L}$ of $85 \% \mathrm{H}_{3} \mathrm{PO}_{4}$ with the additions of $125 \mathrm{~g}$ $\mathrm{Ca}\left(\mathrm{NO}_{3}\right)_{2} \cdot 4 \mathrm{H}_{2} \mathrm{O}, 125 \mathrm{~g} \mathrm{Mg}\left(\mathrm{NO}_{3}\right)_{2} \cdot 6 \mathrm{H}_{2} \mathrm{O}, 125 \mathrm{~g} \mathrm{Zn}\left(\mathrm{NO}_{3}\right)_{2} \cdot 6 \mathrm{H}_{2} \mathrm{O}$, and $125 \mathrm{~g} \mathrm{Cu}\left(\mathrm{NO}_{3}\right)_{2} \cdot 3 \mathrm{H}_{2} \mathrm{O}$.

\section{Summary}

These studies allowed us to conclude that voltages ranging from $500 \mathrm{~V}_{\mathrm{DC}}$ to $650 \mathrm{~V}_{\mathrm{DC}}$ result in the formation of porous coatings enriched with phosphorus, oxygen, calcium, copper, magnesium, 
and zinc on titanium after the Plasma Electrolytic Oxidation process. It should be pointed out that, for the first time, the new electrolyte containing $85 \%$ concentrated phosphoric acid $\left(\mathrm{H}_{3} \mathrm{PO}_{4}\right)$ with the addition of calcium nitrate $\mathrm{Ca}\left(\mathrm{NO}_{3}\right)_{2} \cdot 4 \mathrm{H}_{2} \mathrm{O}$, magnesium nitrate $\mathrm{Mg}\left(\mathrm{NO}_{3}\right)_{2} \cdot 6 \mathrm{H}_{2} \mathrm{O}$, zinc nitrate $\mathrm{Zn}\left(\mathrm{NO}_{3}\right)_{2} \cdot 6 \mathrm{H}_{2} \mathrm{O}$, and copper nitrate $\mathrm{Cu}\left(\mathrm{NO}_{3}\right)_{2} \cdot 3 \mathrm{H}_{2} \mathrm{O}$, was used by the authors. It was observed that the external porosity of the obtained coatings may be described by $3 \mathrm{D}$ roughness parameters, such as the arithmetical mean height $(S a)$ and maximum height $(\mathrm{Sz})$. Between the surfaces of the PEO coating obtained at voltages of $500 \mathrm{~V}_{\mathrm{DC}}$ and $575 \mathrm{~V}_{\mathrm{DC}}$, there is no significant difference among the 3D roughness parameters; this was confirmed by a statistical rank score test at the level of significance $\alpha=0.05$, while that formed at $650 \mathrm{~V}_{\mathrm{DC}}$ shows a different porosity, which was confirmed by the same statistical test. The chemical composition studies, based on EDS measurements, have shown that with increasing PEO voltage, the metal-to-phosphorus ratios also increase, while the XPS studies of the top $10 \mathrm{~nm}$ of PEO coatings show that the maximum of that ratio (0.332) was recorded at $575 \mathrm{~V}_{\mathrm{DC}}$. It should be noted that the chemical composition is not the same in the whole volume of these coatings. In addition, the top $10 \mathrm{~nm}$ of porous coatings are most likely composed of titanium $\left(\mathrm{Ti}^{4+}\right)$, calcium $\left(\mathrm{Ca}^{2+}\right)$, magnesium $\left(\mathrm{Mg}^{2+}\right)$, zinc $\left(\mathrm{Zn}^{2+}\right)$, copper $\left(\mathrm{Cu}^{2+}\right.$ and $\left.\mathrm{Cu}^{+}\right)$, and phosphates $\left(\mathrm{PO}_{4}{ }^{3-}\right.$ and $/$ or $\mathrm{HPO}_{4}{ }^{2-}$, and $/$ or $\mathrm{H}_{2} \mathrm{PO}_{4}{ }^{-}$, and / or $\mathrm{P}_{2} \mathrm{O}_{7}{ }^{4-}$ ). It should be also pointed out that, in the obtained structure of PEO coatings for one zinc atom or one copper atom, which are bactericidal, there may be up to 16 calcium and 29 magnesium atoms, as it was observed in the coatings formed at voltage $575 \mathrm{~V}_{\mathrm{DC}}$. Based on the GDOES and XRD studies, it was found that the higher voltage, the thicker the PEO coating, i.e., the thickest coating may be obtained at $650 \mathrm{~V}_{\mathrm{DC}}$ and the thinnest at $500 \mathrm{~V}_{\mathrm{DC}}$, which is more amorphous with a crystalline phase $\mathrm{Ti}_{2} \mathrm{P}_{2} \mathrm{O}_{7}$. The three sub-layer model for PEO coating description was used, i.e., the authors proposed the following three sublayers: the top, porous one (contaminated with carbon-nitrogen-oxygen compounds originating from the air and cleaning process), the second, semiporous one (enriched in phosphorus, oxygen, calcium, copper, magnesium, and zinc, and depleted in titanium), and a transition one (increasing the amount of titanium, with decreasing amounts of phosphorus, oxygen, calcium, copper, magnesium, and zinc). In summary, it should be noted that the obtained porous coatings, which are enriched in selected elements such as calcium, phosphorus, magnesium, and bactericidal copper and zinc, can be used to increase the biocompatibility of titanium biomaterials, as well as for the creation of new substrates for catalysts with highly developed surface stereometries.

Author Contributions: K.R. and T.H. conceived and designed the experiments; K.R., S.G., P.C., S.R., D.M., K.T., and W.M. performed the experiments; K.R., T.H., W.K., K.T., Ł.D., and K.P. analyzed the data; K.R., T.H., Ł.D. and K.P. contributed reagents, materials, analysis tools; K.R. and T.H. wrote the paper.

Acknowledgments: This work was supported by a subsidy from Grant OPUS 11 of National Science Centre, Poland, with registration number 2016/21/B/ST8/01952, titled "Development of models of new porous coatings obtained on titanium by Plasma Electrolytic Oxidation in electrolytes containing phosphoric acid with addition of calcium, magnesium, copper and zinc nitrates".

Conflicts of Interest: The authors declare no conflict of interest.

\section{References}

1. Wang, Y.; Jiang, B.; Lei, T.; Guo, L. Dependence of growth features of microarc oxidation coatings of titanium alloy on control modes of alternate pulse. Mater. Lett. 2004, 58, 1907-1911. [CrossRef]

2. Sowa, M.; Lastowka, D.; Kukharenko, A.I.; Korotin, D.M.; Kurmaev, E.Z.; Cholakh, S.O.; Simka, W. Characterisation of anodic oxide films on zirconium formed in sulphuric acid: XPS and corrosion resistance investigations. J. Solid State Electrochem. 2017, 21, 203-210. [CrossRef]

3. Sowa, M.; Kazek-Kęsik, A.; Socha, R.P.; Dercz, G.; Michalska, J.; Simka, W. Modification of tantalum surface via plasma electrolytic oxidation in silicate solutions. Electrochim. Acta 2013, 114, 627-636. [CrossRef]

4. Pereira, B.L.; Lepienski, C.M.; Mazzaro, I.; Kuromoto, N.K. Apatite grown in niobium by two-step plasma electrolytic oxidation. Mater. Sci. Eng. C Mater. Biol. Appl. 2017, 77, 1235-1241. [CrossRef] [PubMed]

5. Korkmaz, K. The effect of Micro-arc Oxidation treatment on the microstructure and properties of open cell Ti6Al4V alloy foams. Surf. Coat. Technol. 2015, 272, 72-78. [CrossRef] 
6. Simka, W.; Nawrat, G.; Chlode, J.; Maciej, A.; Winiarski, A.; Szade, J.; Radwanski, K.; Gazdowicz, J. Electropolishing and anodic passivation of Ti6Al7Nb alloy. Przem. Chem. 2011, 90, 84-90.

7. Rokosz, K.; Hryniewicz, T.; Raaen, S.; Chapon, P. Investigation of porous coatings obtained on Ti-Nb-Zr-Sn alloy biomaterial by Plasma Electrolytic Oxidation: Characterisation and Modelling. Int. J. Adv. Manuf. Technol. 2016, 87, 3497-3512. [CrossRef]

8. Siu, H.T.; Man, H.C. Fabrication of bioactive titania coating on nitinol by plasma electrolytic oxidation. Appl. Surf. Sci. 2014, 274, 181-187. [CrossRef]

9. Sowa, M.; Piotrowska, M.; Widziołek, M.; Dercz, G.; Tylko, G.; Gorewoda, T.; Osyczka, A.M.; Simka, W. Bioactivity of coatings formed on Ti13Nb13Zr alloy using plasma electrolytic oxidation. Mater. Sci. Eng. C 2015, 49, 159-173. [CrossRef] [PubMed]

10. Simka, W.; Sadowski, A.; Warczak, M.; Iwaniak, A.; Dercz, G.; Michalska, J.; Maciej, A. Modification of titanium oxide layer by calcium and phosphorus. Electrochim. Acta 2011, 56, 8962-8968. [CrossRef]

11. Villapún, V.M.; Dover, L.G.; Cross, A.; González, S. Antibacterial Metallic Touch Surfaces. Materials 2016, 9 , 736. [CrossRef] [PubMed]

12. Jansson, T.; Clare-Salzler, Z.J.; Zaveri, T.D.; Mehta, S.; Dolgova, N.V.; Chu, B.H.; Ren, F.; Keselowsky, B.G. Antibacterial effects of zinc oxide nanorod surfaces. J. Nanosci. Nanotechnol. 2012, 12, 7132-7138. [CrossRef] [PubMed]

13. Rokosz, K.; Hryniewicz, T.; Gaiaschi, S.; Chapon, P.; Raaen, S.; Pietrzak, K.; Malorny, W.; Fernandes, J.S. Characterization of Porous Phosphate Coatings Enriched with Magnesium or Zinc on CP Titanium Grade 2 under DC Plasma Electrolytic Oxidation. Metals 2018, 8, 112. [CrossRef]

14. Aliasghari, S.; Němcová, A.; Skeldon, P.; Thompson, G.E. Influence of coating morphology on adhesive bonding of titanium pre-treated by plasma electrolytic oxidation. Surf. Coat. Technol. 2016, 289, 101-109. [CrossRef]

15. Gnedenkov, S.V.; Sharkeev, Y.P.; Sinebryukhov, S.L.; Khrisanfova, O.A.; Legostaeva, E.V.; Zavidnaya, A.G.; Puz', A.V.; Khlusov, I.A.; Opra, D.P. Functional coatings formed on the titanium and magnesium alloys as implant materials by plasma electrolytic oxidation technology: Fundamental principles and synthesis conditions. Corros. Rev. 2016, 34, 65-83. [CrossRef]

16. Hariprasad, S.; Ashfaq, M.; Arunnellaiappan, T.; Harilal, M.; Rameshbabu, N. Role of electrolyte additives on in-vitro corrosion behavior of DC plasma electrolytic oxidization coatings formed on CP-Ti. Surf. Coat. Technol. 2016, 292, 20-29.

17. Huang, Q.; Elkhooly, T.A.; Liu, X.; Zhang, R.; Yang, X.; Shen, Z.; Feng, Q. Effects of hierarchical micro/nano-topographies on the morphology, proliferation and differentiation of osteoblast-like cells. Colloid Surf. B Biointerfaces 2016, 145, 37-45. [CrossRef] [PubMed]

18. Kung, K.C.; Yuan, K.; Lee, T.M.; Lui, T.S. Effect of heat treatment on microstructures and mechanical behavior of porous SrCaP coatings on titanium. J. Alloy. Compd. 2012, 515, 68-73. [CrossRef]

19. Zhou, R.; Wei, D.; Cheng, S.; Zhou, Y.; Jia, D.; Wang, Y.; Li, B. The effect of titanium bead diameter of porous titanium on the formation of micro-arc oxidized TiO2-based coatings containing Si and Ca. Ceram. Int. 2013, 39, 5725-5732. [CrossRef]

20. Venkateswarlu, K.; Rameshbabu, N.; Sreekanth, D.; Sandhyarani, M.; Bose, A.; Muthupandi, V.; Subramanian, S. Role of electrolyte chemistry on electronic and in vitro electrochemical properties of micro-arc oxidized titania films on Cp Ti. Electrochim. Acta 2013, 105, 468-480.

21. Çelik, İ.; Alsaran, A.; Purcek, G. Effect of different surface oxidation treatments on structural, mechanical and tribological properties of ultrafine-grained titanium. Surf. Coat. Technol. 2014, 258, 842-848. [CrossRef]

22. Komiya, S.; Sakamoto, K.; Ohtsu, N. Structural changes of anodic layer on titanium in sulfate solution as a function of anodization duration in constant current mode. Appl. Surf. Sci. 2014, 296, 163-168. [CrossRef]

23. Liu, W.; Cheng, M.; Wahafu, T.; Zhao, Y.; Qin, H.; Wang, J.; Zhang, X.; Wang, L. The in vitro and in vivo performance of a strontium-containing coating on the low-modulus Ti35Nb2Ta3Zr alloy formed by micro-arc oxidation. J. Mater. Sci. Mater. M 2015, 26, 1-13. [CrossRef] [PubMed]

24. Zhang, R.F.; Qiao, L.P.; Qu, B.; Zhang, S.F.; Chang, W.H.; Xiang, J.H. Biocompatibility of micro-arc oxidation coatings developed on Ti6Al4V alloy in a solution containing organic phosphate. Mater. Lett. 2015, 153, 77-80. [CrossRef] 
25. Sharifi, H.; Aliofkhazraei, M.; Darband, G.B.; Rouhaghdam, A.S. Tribological properties of PEO nanocomposite coatings on titanium formed in electrolyte containing ketoconazole. Tribol. Int. 2016, 102, 463-471. [CrossRef]

26. Koblova, E.A.; Ustinov, A.Y.; Rudnev, V.S.; Lukiyanchuk, I.V.; Chernykh, I.V. An X-ray photoelectron spectroscopy study of $\mathrm{Ni}$, Cu-containing coatings formed by plasma electrolytic oxidation on aluminum and titanium. J. Struct. Chem. 2017, 58, 1129-1136. [CrossRef]

27. Wang, L.; Erasquin, U.J.; Zhao, M.; Ren, L.; Zhang, M.Y.; Cheng, G.J.; Wang, Y.; Cai, C. Stability, Antimicrobial Activity, and Cytotoxicity of Poly(amidoamine) Dendrimers on Titanium Substrates. ACS Appl. Mater. Interfaces 2011, 3, 2885-2894. [CrossRef] [PubMed]

28. Rokosz, K.; Hryniewicz, T.; Matysek, D.; Raaen, S.; Valíček, J.; Dudek, Ł.; Harničarova, M. SEM, EDS and XPS analysis of the coatings obtained on titanium after plasma electrolytic oxidation in electrolytes containing copper nitrate. Materials 2016, 9, 318. [CrossRef] [PubMed]

29. Rokosz, K.; Hryniewicz, T.; Gaiaschi, S.; Chapon, P.; Raaen, S.; Pietrzak, K.; Malorny, W. Characterisation of calcium- and phosphorus-enriched porous coatings on CP Titanium Grade 2 fabricated by plasma electrolytic oxidation. Metals 2017, 7, 354. [CrossRef]

30. Nelis, T.; Payling, R. Practical Guide to Glow Discharge Optical Emission Spectroscopy; RSC Analytical Spectroscopy Monographs; Barnett, N.W., Ed.; Royal Society of Chemistry: Cambridge, UK, 2002.

31. Casa Software Ltd. CasaXPS: Processing Software for XPS, AES, SIMS and More. 2009. Available online: http:/ / www.casaxps.com (accessed on 24 May 2018).

32. Naumkin, A.V.; Kraut-Vass, A.; Gaarenstroom, S.W.; Powell, C.J. NIST X-ray Photoelectron Spectroscopy Database: NIST Standard Reference Database 20, Version 4.1. 2012. Available online: https:/ /srdata.nist. gov/xps/ (accessed on 24 May 2018).

33. Moulder, J.F.; Stickle, W.F.; Sobol, P.E.; Bomben, K.D. Handbook of X-ray Photoelectron Spectroscopy; Chastain, J., Ed.; Perkin-Elmer Corporation: Eden Prairie, MN, USA, 1992.

(C) 2018 by the authors. Licensee MDPI, Basel, Switzerland. This article is an open access article distributed under the terms and conditions of the Creative Commons Attribution (CC BY) license (http:/ / creativecommons.org/licenses/by/4.0/). 